\title{
Performance of Sunnhemp (Crotalaria juncea L.) as a Summer Season (Pre-Monsoon) Crop for Fibre
}

\author{
M. K. Tripathi ${ }^{1}$, Babita Chaudhary ${ }^{1}$, S. K. Sarkar ${ }^{2}$, S. R. $\operatorname{Singh}^{2}$, H. R. Bhandari ${ }^{1}$ \& B. S. Mahapatra ${ }^{2}$ \\ ${ }^{1}$ Sunnhemp Research Station (CRIJAF, ICAR), Pratapgarh, U. P., India \\ ${ }^{2}$ Central Research Institute for Jute and Allied Fibres (ICAR), Barrackpore, W. B., India \\ Correspondence: M. K. Tripathi, Sunnhemp Research Station (CRIJAF, ICAR), Pratapgarh, U. P., India. E-mail: \\ sanaipbh@gmail.com; mktripathi72@gmail.com
}

$\begin{array}{lc}\text { Received: December 5, } 2012 & \text { Accepted: January 22, } 2013 \quad \text { Online Published: February 17, } 2013 \\ \text { doi:10.5539/jas.v5n3p236 } & \text { URL: http://dx.doi.org/10.5539/jas.v5n3p236 }\end{array}$

\begin{abstract}
The field experiments were conducted during the summer (pre-monsoon) seasons of 2008-2009 and 2009-2010 at Sunnhemp Research Station, CRIJAF-ICAR, Pratapgarh, U.P., India to assess the feasibility of sunnhemp cultivation for fibre purpose during summer season after harvest of wheat crop. The experiments were laid out in randomized block design. The data from different experiments indicated that sowing of sunnhemp crop for fibre purpose during $2^{\text {nd }}$ fortnight of April at the spacing of $15 \mathrm{~cm} \times 10 \mathrm{~cm}$ and harvesting at 90 days after sowing recorded higher fibre yield. The summer season crop escaped from the attack of most of the insect pest besides allowing time for the transplanting of rice crop also. The results indicated that sunnhemp could be easily accommodated in prevailing rice-wheat cropping system during summer season.
\end{abstract}

Keywords: date of sowing, spacing, time of harvesting, fibre yield

\section{Introduction}

Crotalaria juncea L. belongs to Fabaceae family widely distributed in the tropical and subtropical regions of India, Nepal, Sri Lanka and Southern Africa. It is commonly known as Sunhemp or Indian hemp (Kirtikar \& Basu, 1999). It is one of the oldest known fibre crops which produces white strong bast fibre from its bark having greater tensile strength and is more durable under exposure than jute. The fibre has high cellulose content, low lignin and negligible ash. It has been identified as the most suitable indigenous raw material for manufacturing of high quality tissue paper, cigarette paper and paper for currency (Chawla et al., 1967). In India traditionally it is used for making ropes, twines, net, handmade paper, tat-patties and canvas (Tripathi et al., 2012). It is also grown for green manuring (Sarkar \& Ghoroi, 2007) and fodder purposes. It is used as a medicine, edible and culinary purpose by many tribal communities (Chopra et al., 1956). It is used as blood purifier, abortificient, astringent, demulcent, emetic, purgative and in the treatment of anaemia, impetigo, menorrhagia and psoriasis (Bhatt et al., 2009). The crop suppresses weeds, reduces soil erosion and controls root knot nematode populations (Rotar \& Joy, 1983). The crop is traditionally grown during kharif season with the onset of monsoon. But with the advent of green revolution, the acreage under sunnhemp crop reduced drastically and shifted towards irrigated transplanted kharif (monsoon season) rice crop due to various reasons. The sunnhemp could not compete with the rice crop and thus rice-wheat cropping system occupied most of the traditional areas of sunnhemp. The importance of natural fibre is again getting momentum and thus there is urgent need to accommodate the sunnhemp crop in prevailing rice-wheat cropping system. In northern India a large acreage of cultivated land lying fallow during summer (pre-monsoon) season after harvest of wheat crop could be utilized for sunnhemp cultivation. Inclusion of sunnhemp in rice-wheat cropping system not only increases the system productivity but increase soil fertility too. Keeping these points in view, the present investigation was undertaken to assess the performance of sunnhemp cultivation for fibre purpose during summer (pre-monsoon) season fallow after harvest of wheat crop.

\section{Materials and Methods}

The field experiments were conducted for consecutive two years during the summer seasons (pre-monsoon) of 2008-2009 and 2009-2010 at the research farm of Sunnhemp Research Station, CRIJAF-ICAR, Pratapgarh, Uttar Pradesh, India. The experimental soil was sandy loam in texture with $\mathrm{pH} 7.7$, organic carbon $3.1 \mathrm{~g} / \mathrm{kg}$, available nitrogen $(\mathrm{N})$, phosphorus $\left(\mathrm{P}_{2} \mathrm{O}_{5}\right)$ and potassium $\left(\mathrm{K}_{2} \mathrm{O}\right) 230,10.2$ and $180 \mathrm{~kg} / \mathrm{ha}$, respectively. The experiments 
were laid out in randomized block design. Total four numbers of experiments were conducted using different treatments (Tables 1-4). The recommended dose of NPK for sunnhemp was 20:40:20 kg/ha. The sources of nitrogenous, phosphatic and potassic fertilizers were urea, single super phosphate and muriate of potash, respectively and were applied at the time of sowing as basal dose. The seed was treated with carbendazim as per treatment and dried in shade before sowing in experiment-4. The sunnhemp variety SH-4 was sown in line with a row to row spacing of $20 \mathrm{~cm}$ except in experiment- 2 where it was sown as per treatment. All the experiments were sown during $2^{\text {nd }}$ fortnight of April during both the years except experiment-1, which was sown as per treatment. The thinning operation was carried out during 10-15 days of sowing to maintain a plant to plant spacing of 5-7 cm except in experiment- 2 where it was maintained according to treatment. Need based irrigation was applied to the crop. The spraying of plant protection chemical was done as per treatment in experiment- 4 . The matured crop was harvested after 90 days of sowing except in experiment- 3 where the crop was harvested as per treatment. The upper tender portions $(25 \mathrm{~cm})$ of the harvested plants were cut and removed after that remaining plants were tied in small bundles of about $30 \mathrm{~cm}$ diameter. The bundles were immersed horizontally in the water of the retting tank. Bamboo and wooden logs were used for proper immersion of the bundles so that at least $10 \mathrm{~cm}$ of water remains on them. After completion of retting which takes 4-5 days, fibre was extracted manually, washed in fresh water, sundried and dry weight was recorded. The same procedure was followed during second year also. The statistical analyses of the experimental data were carried out using STPR (GBPUAT, Pantnagar, Uttara Khand, India).

Table 1. Treatments used in the experiment-1 effect of date of sowing on sunnhemp

\begin{tabular}{cc}
\hline Treatments & Details \\
\hline T1 & Sowing on $1^{\text {st }}$ April \\
T2 & Sowing on $16^{\text {th }}$ April \\
T3 & Sowing on $1^{\text {st }}$ May \\
T4 & Sowing on $16^{\text {th }}$ May \\
T5 & Sowing on $31^{\text {st }}$ May \\
T6 & Sowing on $15^{\text {th }}$ June \\
T7 & Sowing on $30^{\text {th }}$ June \\
\hline
\end{tabular}

Table 2. Treatments used in the experiment-2 effect of spacing on sunnhemp

\begin{tabular}{cc}
\hline Treatments & Details \\
\hline T1 & Broadcasting $(40 \mathrm{~kg} / \mathrm{ha})$ \\
T2 & Sowing at $15 \mathrm{~cm} \times 5 \mathrm{~cm}$ \\
T3 & Sowing at $15 \mathrm{~cm} \mathrm{\times} 10 \mathrm{~cm}$ \\
T4 & Sowing at $20 \mathrm{~cm} \mathrm{\times} 5 \mathrm{~cm}$ \\
T5 & Sowing at $20 \mathrm{~cm} \times 10 \mathrm{~cm}$ \\
T6 & Sowing at $25 \mathrm{~cm} \mathrm{\times} 5 \mathrm{~cm}$ \\
T7 & Sowing at $25 \mathrm{~cm} \mathrm{\times} 10 \mathrm{~cm}$ \\
\hline
\end{tabular}

Table 3. Treatments used in the experiment-3 effect of time of harvest on sunnhemp

\begin{tabular}{cc}
\hline Treatments & Details \\
\hline T1 & Harvesting at 80 DAS \\
T2 & Harvesting at 90 DAS \\
T3 & Harvesting at 100 DAS \\
T4 & Harvesting at 110 DAS \\
T5 & Harvesting at 120 DAS \\
\hline
\end{tabular}


Table 4. Treatments used in the experiment-4 management of insect pest in sunnhemp

\begin{tabular}{cc}
\hline Treatments & Details \\
\hline T1 & Seed treatment (Carbendazim @ $2 \mathrm{~g} / \mathrm{kg})$ \\
T2 & Spraying with Carbendazim $(2 \mathrm{~g} / \mathrm{L})$ \\
T3 & Spraying of Endosulphan $(1.5 \mathrm{ml} / \mathrm{L})$ \\
T4 & Spraying of Carbendzim and Endosulphan \\
T5 & Control \\
\hline
\end{tabular}

\section{Results and Discussion}

\subsection{Experiment-1}

\subsubsection{Plant Height}

Significant variations were observed in plant height of sunnhemp due to different dates of sowing during both the years (Table 5). The data revealed that highest plant height $(244.8 \mathrm{~cm})$ was associated with the sowing of crop on $16^{\text {th }}$ April whereas it was smallest with the sowing of crop on $30^{\text {th }}$ June which coincides with the onset of monsoon. Delayed sowing caused significant reduction in plant height. It was also clear from the data that crop sown on $16^{\text {th }}$ April and $1^{\text {st }}$ May did not differ significantly with respect to plant height. The range of variation in plant height due to different dates of sowing was 35.4 and 32.1\% during 2008-09 and 2009-10, respectively. The increase in plant height may be attributed to more sunshine hours or long day during vegetative growth period as sunnhemp prefers long days during vegetative phase while short days for reproductive phase. The present findings are in close conformity with those of Chaudhary et al. (2007).

Table 5. Yield and yield attributes of sunnhemp as influenced by date of sowing

\begin{tabular}{|c|c|c|c|c|c|c|c|c|c|c|}
\hline \multirow[b]{2}{*}{ Treatments } & \multicolumn{2}{|c|}{$\mathrm{BD}(\mathrm{mm})$} & \multicolumn{2}{|c|}{ PH (cm) } & \multicolumn{2}{|c|}{ GB (q/ha) } & \multicolumn{2}{|c|}{ FY (q/ha) } & \multicolumn{2}{|c|}{ SY (q/ha) } \\
\hline & $\begin{array}{c}2008 \\
-09\end{array}$ & $\begin{array}{c}2009-1 \\
0\end{array}$ & $\begin{array}{c}2008-0 \\
9\end{array}$ & $\begin{array}{c}2009-1 \\
0\end{array}$ & $\begin{array}{c}2008-0 \\
9\end{array}$ & $\begin{array}{c}2009-1 \\
0\end{array}$ & $\begin{array}{c}2008-0 \\
9\end{array}$ & $\begin{array}{c}2009-1 \\
0\end{array}$ & $\begin{array}{c}2008-0 \\
9\end{array}$ & $\begin{array}{c}2009-1 \\
0\end{array}$ \\
\hline $1^{\text {st }}$ April & 10.3 & 8.7 & 218.2 & 200.8 & 324.66 & 264.14 & 6.56 & 6.07 & 36.84 & 34.38 \\
\hline $16^{\text {th }}$ April & 10.4 & 10.0 & 249.4 & 240.2 & 347.22 & 381.94 & 10.16 & 10.01 & 52.48 & 56.35 \\
\hline $1^{\text {st }}$ May & 10.1 & 9.8 & 245.1 & 237.0 & 312.50 & 373.26 & 9.19 & 9.74 & 49.06 & 53.88 \\
\hline $16^{\text {th }}$ May & 9.8 & 9.8 & 220.0 & 232.9 & 252.98 & 359.62 & 7.61 & 9.21 & 38.96 & 51.74 \\
\hline $31^{\text {st }}$ May & 7.9 & 9.4 & 194.3 & 219.5 & 125.25 & 329.86 & 3.72 & 7.98 & 20.37 & 47.72 \\
\hline $15^{\text {th }}$ June & 6.8 & 7.1 & 187.5 & 199.3 & 111.61 & 199.65 & 2.84 & 5.12 & 16.97 & 29.77 \\
\hline $30^{\text {th }}$ June & 5.9 & 6.2 & 184.2 & 181.8 & 93.01 & 125.05 & 2.21 & 3.28 & 14.35 & 18.32 \\
\hline $\mathrm{CD}$ at $5 \%$ & 1.7 & 1.3 & 23.3 & 17.0 & 44.04 & 50.38 & 1.32 & 1.38 & 7.72 & 7.16 \\
\hline
\end{tabular}

\subsubsection{Basal Diameter}

The data recorded over two years of experimentation showed that date of sowing had a significant effect on basal diameter (Table 5). The results revealed that basal diameter increased under the influence of early sowing and decreased continuously with delay in sowing time. The maximum basal diameter was recorded in the crop sown on $16^{\text {th }}$ April followed by the crop sown on $1^{\text {st }}$ May. The minimum basal diameter was observed under the influence of sowing on $30^{\text {th }}$ June means sowing with the onset of monsoon. The increment in basal diameter of the crop sown on $16^{\text {th }}$ April was 76.3 and $61.3 \%$ over $30^{\text {th }}$ June sown crop during first and second year, respectively. The increase in basal diameter under the effect of early sowing might be due to better growth and development of crops in presence of long sunshine days and thus more photosynthesis. These findings corroborate with Chaudhary et al. (2007).

\subsubsection{Green Biomass}

Green biomass of sunnhemp was influenced significantly due to various dates of sowing (Table 5). The result based on two years data clearly indicated that the green biomass increased due to early sowing. The maximum 
green biomass was recorded in crop sown on $16^{\text {th }}$ April followed by the crop sown on $1^{\text {st }}$ May during both the years. The green biomass declined rapidly with delay in sowing and was minimum under the effect of $30^{\text {th }}$ June sown crop. The green biomass yield of sunnhemp reduced more than three times in the crop sown with the onset of monsoon ( $30^{\text {th }}$ June) compared to crop sown on $16^{\text {th }}$ April. The increase in green biomass may be due to increase in plant height, basal diameter and overall growth and development of crop in the presence of long sunshine hours, controlled irrigation, better nutrient and crop management practices during early sown crop. These results are in conformity with the findings of Chaudhary et al. (2007).

\subsubsection{Fibre and Stick Yield}

The fibre and stick yield was significantly influenced by dates of sowing (Table 5). The result of two years experimental data showed that fibre yield increased under the influence of early sowing and declined continuously with delayed sowing. The highest fibre yield $(10.1 \mathrm{q} / \mathrm{ha})$ was noted in the crop sown on $16^{\text {th }}$ April being at par with the crop sown on $1^{\text {st }}$ May during first year while $16^{\text {th }}$ May during second year. The lowest yield of fibre $(2.7 \mathrm{q} / \mathrm{ha})$ was recorded in the crop sown on $30^{\text {th }}$ June during both the years. The fibre yield of sunnhemp sown on $16^{\text {th }}$ April was 3 to 4 times higher over the yield of crop obtained with the sowing on $30^{\text {th }}$ June during both the years. The low fibre yield of the crop sown on $1^{\text {st }}$ April was due to the shorter day length which caused an early floral induction and branching that strongly reduced stem and fibre elongation, and thus aboveground dry biomass and consequently fibre yields whereas in case of delayed sowing it was due to poor growth and development. The crop sown during the month of June was heavily infested by various insects- pests and diseases leading to sharp decline in fibre yield. The increment in fibre yield of sunnhemp sown early during summer season might be due to cumulative effect of better plant height, more basal diameter and more green biomass. The similar trend was observed in stick yield also during both the years. These results are on par with the findings of Pradhan et al. (1999), Chaudhury et al. (2007) and Cosentino et al. (2012).

\subsection{Experiment-2}

\subsubsection{Plant Height}

The effect of planting geometry on plant height was observed significant during both the years (Table 6). The analysed data of two years indicated that plant height increased with increase in row to row and plant to plant spacing. The highest plant height was recorded under the spacing of $20 \mathrm{~cm} \times 10 \mathrm{~cm}$ closely followed by $25 \mathrm{~cm} \times 10$ $\mathrm{cm}$. The plant height decreased under lower spacing and was minimum under $15 \mathrm{~cm} \times 5 \mathrm{~cm}$ spacing. The narrower spacing might have led to intense competition among plants because of population higher than the optimum. The height of plant under broadcasting method of sowing was also low. The better plant height of sunnhemp under 20 $\mathrm{cm} \times 10 \mathrm{~cm}$ of spacing might be due to the availability of more space per plant ultimately more solar radiation, more nutrient and more moisture per plant. This is in conformity to the results of Grabowska and Koziara (2005).

Table 6. Yield and yield attributes of sunnhemp as influenced by spacing

\begin{tabular}{|c|c|c|c|c|c|c|c|c|c|c|}
\hline \multirow{3}{*}{ Treatments } & \multicolumn{2}{|c|}{$\mathrm{BD}(\mathrm{mm})$} & \multicolumn{2}{|c|}{$\mathrm{PH}(\mathrm{cm})$} & \multicolumn{2}{|c|}{ GB (q/ha) } & \multicolumn{2}{|c|}{ FY (q/ha) } & \multicolumn{2}{|c|}{ SY (q/ha) } \\
\hline & 2008 & $2009-1$ & $2008-0$ & $2009-1$ & $2008-0$ & 2009-1 & $2008-0$ & 2009-1 & $2008-0$ & $2009-1$ \\
\hline & -09 & 0 & 9 & 0 & 9 & 0 & 9 & 0 & 9 & 0 \\
\hline $\begin{array}{l}\mathrm{BC}(40 \\
\mathrm{kg} / \mathrm{ha})\end{array}$ & 9.3 & 9.6 & 243.3 & 245.7 & 260.97 & 264.59 & 7.46 & 8.07 & 38.03 & 39.42 \\
\hline $15 \times 5 \mathrm{~cm}$ & 8.7 & 9.4 & 236.7 & 234.3 & 285.93 & 270.43 & 8.26 & 8.26 & 42.21 & 40.45 \\
\hline $15 \times 10 \mathrm{~cm}$ & 10.0 & 10.4 & 246.6 & 247.2 & 318.65 & 332.82 & 9.34 & 10.15 & 46.19 & 50.75 \\
\hline $20 \times 5 \mathrm{~cm}$ & 9.4 & 9.6 & 256.7 & 240.3 & 273.63 & 279.75 & 7.88 & 8.49 & 40.25 & 42.40 \\
\hline $20 \times 10 \mathrm{~cm}$ & 10.6 & 10.8 & 264.9 & 257.7 & 296.31 & 315.39 & 8.64 & 9.60 & 43.31 & 47.97 \\
\hline $25 \times 5 \mathrm{~cm}$ & 9.1 & 9.8 & 251.7 & 248.6 & 269.29 & 292.45 & 7.70 & 8.92 & 39.11 & 43.63 \\
\hline $25 \times 10 \mathrm{~cm}$ & 10.5 & 11.4 & 263.4 & 263.3 & 264.26 & 261.38 & 7.61 & 7.96 & 36.37 & 38.81 \\
\hline $\mathrm{CD}$ at $5 \%$ & 1.2 & 1.3 & 18.6 & 16.6 & 36.05 & 47.25 & 1.17 & 1.45 & 5.03 & 7.11 \\
\hline
\end{tabular}




\subsubsection{Basal Diameter}

The basal diameter of the plants indicated significant variation due to different spacing (Table 6). On the basis of two years data it was clear that basal diameter increased with increase in row to row and plant to plant spacing. The maximum basal diameter was recorded under the spacing of $20 \mathrm{~cm} \times 10 \mathrm{~cm}$ being at par with the basal diameter of plants under $25 \mathrm{~cm} \times 10 \mathrm{~cm}$ spacing. The wider intra-row spacing between the plants enhanced the uptake of nutrients, moisture and ultimately resulted in production of thicker stalks. The basal diameter of the plants decreased with narrower spacing and the minimum was noted in $15 \mathrm{~cm}$ x $5 \mathrm{~cm}$ of spacing. Similar results were reported by Grabowska and Koziara (2005).

\subsubsection{Green Biomass}

The results indicated significant differences in green biomass yield of sunhemp due to different spacing conditions during both the years (Table 6). The maximum green biomass yield was obtained with the spacing of $15 \mathrm{~cm} \times 10$ $\mathrm{cm}$. followed by spacing of $20 \mathrm{~cm} \times 10 \mathrm{~cm}$. The minimum green biomass of sunnhemp was noted under the influence of broadcasting method of sowing being at par with that of $25 \mathrm{~cm} \times 10 \mathrm{~cm}$. The increase in green biomass yield of crop sown at a spacing of $15 \mathrm{~cm} \mathrm{x} 10 \mathrm{~cm}$ was found to the tune of 22.1 and $25.8 \%$ over broadcasting method of sowing in 2008-09 and 2009-10, respectively. The higher yield of green biomass under the spacing of $15 \mathrm{~cm} \times 10 \mathrm{~cm}$ might be attributed to more number of plants per unit urea under this treatment.

\subsubsection{Fibre and Stick Yield}

The variation in fibre yield of sunnhemp was significant due to different planting geometry during both the years (Table 6). Sowing of sunnhemp at the spacing of $15 \mathrm{~cm} \mathrm{x} 10 \mathrm{~cm}$ produced significantly higher fibre $(9.34 \& 10.15$ $\mathrm{q} / \mathrm{ha})$ and stick yield $(46.19 \& 50.75 \mathrm{q} / \mathrm{ha})$ over normal broadcast method in both the years. The fibre yield obtained with the spacing of $20 \mathrm{~cm} \times 10 \mathrm{~cm}$ was at par with the spacing of $15 \mathrm{~cm} \times 10 \mathrm{~cm}$. The lowest fibre yield was noted under broadcast method of sowing being on par with the fibre yield of $25 \times 10 \mathrm{~cm}$ spacing. Sowing of crop in rows $(15 \mathrm{~cm} \times 10 \mathrm{~cm})$ gave 25.2 and $25.8 \%$ more fibre yield when compared with broadcasting method of sowing during 2008-09 and 2009-10, respectively. The higher fibre yield associated with spacing of $15 \mathrm{~cm} \mathrm{x} 10 \mathrm{~cm}$ might be attributed to higher plant population and green biomass under this treatment. Similar results were recorded by Ulemale et al. (2002).

\subsection{Experiment-3}

\subsubsection{Plant Height}

The perusal of data on plant height indicated significant variation due to time of harvest (Table 7). The highest plant height of sunnhemp was obtained with the crop harvested at 120 days after sowing which was at par with harvesting at 90,100 and 110 days after sowing during both the years. The lowest plant height was noted with the crop harvested at 80 days after sowing. The increase in plant height may be attributed to longer growing period available to the plants.

Table 7. Yield and yield attributes of sunnhemp as influenced by time of harvest

\begin{tabular}{|c|c|c|c|c|c|c|c|c|c|c|}
\hline \multirow{3}{*}{ Treatments } & \multicolumn{2}{|c|}{$\mathrm{BD}(\mathrm{mm})$} & \multicolumn{2}{|c|}{$\mathrm{PH}(\mathrm{cm})$} & \multicolumn{2}{|c|}{ GB (q/ha) } & \multicolumn{2}{|c|}{ FY (q/ha) } & \multicolumn{2}{|c|}{ SY (q/ha) } \\
\hline & 2008 & 2009-1 & $2008-0$ & 2009-1 & $2008-0$ & 2009-1 & $2008-0$ & 2009-1 & $2008-0$ & $2009-1$ \\
\hline & -09 & 0 & 9 & 0 & 9 & 0 & 9 & 0 & 9 & 0 \\
\hline 80 DAS & 8.8 & 9.0 & 219.4 & 221.6 & 220.28 & 312.73 & 5.37 & 7.20 & 27.18 & 38.09 \\
\hline 90 DAS & 9.3 & 9.4 & 235.3 & 238.3 & 244.40 & 349.50 & 6.35 & 8.82 & 34.23 & 48.34 \\
\hline 100 DAS & 9.5 & 9.6 & 242.9 & 246.0 & 257.73 & 364.52 & 6.72 & 9.37 & 37.35 & 53.79 \\
\hline 110 DAS & 9.6 & 9.9 & 245.2 & 252.3 & 266.13 & 373.89 & 6.99 & 9.72 & 39.51 & 56.48 \\
\hline 120 DAS & 9.8 & 9.9 & 247.2 & 255.6 & 270.56 & 378.73 & 7.14 & 9.93 & 40.39 & 57.83 \\
\hline $\mathrm{CD}$ at $5 \%$ & NS & NS & 19.0 & 17.8 & 34.02 & 45.00 & 0.97 & 1.48 & 6.87 & 7.06 \\
\hline
\end{tabular}

\subsubsection{Basal Diameter}

The data recorded from the sunnhemp crop indicated that basal diameter increased when the harvesting was delayed during both the years (Table 7). Though the variation among different treatments were non-significant. The maximum basal diameter was noticed with the plants harvested at 120 days after sowing whereas it was lowest 
in the crop harvested at 80 days after sowing. The reduction in basal diameter of plants harvested at 80 days after sowing may be attributed to availability of less time for their growth and development.

\subsubsection{Green Biomass}

The time of harvesting significantly influenced the green biomass yield of sunnhemp during both the years (Table 7). Crop harvested at 120 days after sowing recorded maximum green biomass yield but was statistically at par with the biomass yield of crop harvested at 90,100 and 110 days after sowing. The lowest values of green biomass yield were observed in the crop harvested at 80 days after sowing. The lesser amount of green biomass under this treatment might be due to reduction in plant height and basal diameter resulting into poor growth and development of crop.

\subsubsection{Fibre and Stick Yield}

The effect of time of harvest was found significant with respect to fibre and stick yield of sunnhemp during both the years (Table 7). It is clear from the data that harvesting at 120 days after sowing recorded highest fibre and stick yield but was not significantly superior to the yield of crop harvested at 90, 100 and 110 days after sowing. The variation in fibre yield of crop due to time of harvesting was noted to the tune of 33.0 and $37.9 \%$ between 80 and 120 days of harvesting during 2008-09 and 2009-10. The higher values of fibre and stick yield were probably owing to better plant height, increased basal diameter and more green biomass. The lowest fibre and stick yield was recorded with the crop harvested at 80 days after sowing. The reduction in fibre yield of crop harvested at 80 days after sowing may be attributed to availability of lesser time span for the development of fibre in bark of plants.

\subsection{Experiment-4}

It is evident from the data recorded over two years that variations among different treatments were non-significant (Table 8). From the data it was noticed that sunnhemp crop sown during summer season escapes most of the insect pest. The attack of insect pest was negligible due to which no significant differences were noted in plant height, basal diameter and fibre yield due to different treatments. This might be owing to high temperature, absence of cloudy weather and low humidity during summer season. The similar findings in summer crop of sunnhemp were reported by Sarkar et al. (1998), Pradhan et al. (1999), Sarkar and Tripathi (2003) and Ramasubramanian et al. (2010).

Table 8. Yield and yield attributes of sunnhemp as influenced by insect pest management practices

\begin{tabular}{|c|c|c|c|c|c|c|}
\hline \multirow{2}{*}{ Treatments } & \multicolumn{2}{|c|}{$\mathrm{BD}(\mathrm{mm})$} & \multicolumn{2}{|c|}{$\mathrm{PH}(\mathrm{cm})$} & \multicolumn{2}{|c|}{ FY (q/ha) } \\
\hline & $2008-09$ & $2009-10$ & $2008-09$ & $2009-10$ & $2008-09$ & $2009-10$ \\
\hline $\begin{array}{l}\text { T1- Seed treatment (Carbendazim } \\
(2,2 \mathrm{~g} / \mathrm{kg})\end{array}$ & 10.4 & 9.4 & 244.1 & 225.4 & 6.10 & 8.51 \\
\hline T2- Spraying with Carbendazim $(2 \mathrm{~g} / \mathrm{L})$ & 10.2 & 8.9 & 238.4 & 216.6 & 6.35 & 8.08 \\
\hline T3- Spraying of Endosulfan $(1.5 \mathrm{ml} / \mathrm{L})$ & 10.1 & 9.0 & 242.5 & 221.4 & 6.79 & 8.34 \\
\hline $\begin{array}{l}\text { T4- Spraying of Carbendazim \& } \\
\text { Endosulfan }\end{array}$ & 9.8 & 9.5 & 232.9 & 230.1 & 6.57 & 8.45 \\
\hline T5- Control & 10.3 & 8.8 & 246.2 & 220.0 & 6.16 & 7.94 \\
\hline $\mathrm{CD}$ at $5 \%$ & NS & NS & NS & NS & NS & NS \\
\hline
\end{tabular}

\section{Conclusion}

From the present study it is clear that sowing of sunnhemp crop for fibre purpose during $2^{\text {nd }}$ fortnight of April at the spacing of $15 \mathrm{~cm} \times 10 \mathrm{~cm}$ and harvesting at 90 days after sowing produced higher fibre yield. The summer season crop escaped from the attack of most of the pest and diseases besides allowing time for the transplanting of rice crop also. The results indicated that sunnhemp can be easily accommodated in prevailing rice-wheat cropping system during summer season. 


\section{References}

Bhatt, K. C., Pandey, A., Dhariwal, O. P., Panwar, N. S., \& Bhandari, D. C. (2009). Tum-thang (Crotalaria tetragona Roxb. Ex Andr.): A little known wild edible species in the north-eastern hill region of India. Genet Resour Crop Evol., 56, 729-733. http://dx.doi.org/10.1007/s10722-009-9428-0

Chaudhury, J., Singh, D. P., \& Hazra, S. K. (2007). Sunnhemp (Crotalaria juncea L.). Monograph, Central Research Institute for Jute and Allied Fibres (pp. 1-45). Barrackpore, West Bengal, India.

Chawla, J. S., Sharma, A. N., \& Abrol, B. K. (1967). Indian Pulp Pap., 22(5), 285.

Chopra, R. N., Naayar, S. L., \& Chopra, I. C. (1956). In: Glossary of Indian medicinal plant. New Delhi, India: Council of Scientific and Industrial Research.

Cosentino, S. L., Testa, G., Scordia, D., Copani, V. (2012). Sowing time and prediction of flowering of different hemp (Cannabis sativa L.) genotypes in southern Europe. Industrial Crops and Products, 37(1), 20-33. http://dx.doi.org/10.1016/j.indcrop.2011.11.017

Grabowska, L., \& Koziara, W. (2005). The effect of nitrogen dose, sowing density and time of harvest on development and yields of hemp cultivar Bialobrzeskie. Journal of Natural Fibers, 2(4), 1-17.

Kritikar, K. R., \& Basu, B. D. (1999). Indian medicinal plants, 1. New Delhi: International Book Dis.

Pradhan, S. K., Prakash, S., Sarkar, S. K., Singh, A. P., \& Tripathi, S. N. (1999). Fifty years of research on jute and allied fibres agriculture: A golden jubilee volume (pp. 203-209). Barrackpore, Kolkata: CRIJAF.

Ramasubramanian, T., Sarkar. S. K., Satpathy, S., Laha, S. K., De, R. K., Gotyal, B. S., ... Biswas, C. (2010). Integrated pest and disease management for jute and allied fibres. Indian Farming, 59(12), 33-39\&47.

Rotar, P. P., \& Joy, R. J. (1983). 'Tropic Sun' sunn hemp, Crotalaria juncea L. Research Extension Series 036. College of Tropical Agriculture and Human Resources, University of Hawaii.

Sarkar, S .K, Prakash, S., \& Pradhan, S. K. (1998). Influence of dates of sowing, fertilizer levels and varieties on the incidence of wilt (Fusarium udum f.sp. crotalaria) in Sunnhemp (Crotalaria juncea Linn). Legume Research, 21(3-4), 225-228

Sarkar, S. K., \& Tripathi, M. K. (2003). Summer crop of sunnhemp escape major pests and diseases. ICAR News, 9(4), 16.

Sarkar, S. K., \& Ghoroi, A. K. (2007). Sunnhemp as a green manure. International Journal of Agricultural Sciences, 3(1), 244-248.

Tripathi, M. K., Chaudhary, B., Bhandari, H. R., \& Harish, E. R. (2012). Effect of varieties, irrigation and nitrogen management on fibre yield of sunnhemp. Journal of Crop and Weed, 8(1), 84-85.

Ulemale, R. B., Giri, D. G., \& Shivankar, R. S. (2002). Effect of sowing dates, row spacings and phosphate levels on seed vigour and fibre yield in sunnhemp (Crotolaria juncea L.). Annals of Plant Physiology, 16(1), 84-86. 